\title{
SIMBOLISME SENI DALAM BUDAYA JAWA DI ERA GLOBAL: SUATU KAJIAN DARI BATIK DAN TARI KLASIK GAYA YOGYAKARTA Oleh: Dina Dwikurniarini ${ }^{1}$
}

\begin{abstract}
Abstrak
Globalisasi adalah suatu kondisi yang tidak dapat dihindarkan sehingga dapat mempengaruhi dan mengubah berbagai hal di dunia ini. Kebudayaan juga mengalami banyak perubahan karena perkembangan komunikasi maupun teknologi. Tulisan ini mencoba menjelaskan faktor-faktor apa saja yang terjadi pada budaya Indonesia karena proses perubahan tersebut. Batik dan tari adalah kebudayaan khas Indonesia yang sudah berumur paling tidak sama dengan umur Yogyakarta. Penciptaan motif dalam batik maupun tari mengandung makna tertentu, sehingga benar-benar ditujukan untuk maksud tertentu, seperti gerak tari yang melambangkan kegagahberanian dan kelembutan. Demikian juga dengan batik yang ditujukan untuk kemuliaan, kebahagian bagi pemakainya, sehingga orang akan memilih mana yang paling tepat digunakannya pada keperluan tertentu.

Perkembangan teknologi dan komunikasi menjadikan kebudayaan mengalami perkembangan yang sangat beragam tergantung pada sebesar apa pengaruh itu datang. Simbolisme dalam budaya Jawa mulai terkikis juga karena kepentingan pasar sebagai orientasi utama globaliisasi. Batik diciptakan menerjang aturan-aturan motif demi pasar seperti warna, motif yang dipadukan dengan berbagai gaya dan selera masa kini. Pada akhirnya akan menghasilkan seni budaya indah dalam konteks kekinian dan bukan keindahan dalam konteks klasik. Artinya ada pergeseran kepentingan demi kebutuhan manusia dan itu juga merupakan suatu keuntungan untuk perkembangan budaya sendiri yang makin mendunia.

Untuk mempertahankan tradisi klasik bukan hal yang mudah saat ini, karena orientasi budaya juga mengalami perubahan kepentingan. Tulisan ini akan mencoba menyoroti bidang-bidang itu dari aspek historis dan ekonomis suatu perjalanan budaya lokal yang adiluhung dari batik dan tari klasik.
\end{abstract}

Kata Kunci: Batik, globalisasi, dan simbolisme.

\section{A. Pendahuluan}

Beragamnya suku bangsa yang hidup di Indonesia membawa ciri kebudayaannya masing-masing seperti seni pertunjukkannya yang memiliki

\footnotetext{
${ }^{1}$ Staf Pengajar Jurusan Pendidikan Sejarah FIS UNY
} 
karakteristik nilai etik dan estetika tinggi. Seni tari klasik adalah salah satunya yang dilukiskan sebagai suatu hasil karya rohani manusia yang antik dan diciptakan masa Sultan Hamangku Buwono pertama yang bertahta antara 1755-1794. Tarian kuno juga mengandung nilai-nilai historis, heroik dan adiluhung. Tarian klasik berasal dari filsafat lama yaitu “joged Mataram”, telah dikembangkan ke luar keraton sejak Krida Beksan Wirama didirikan 17 Agustus 1918. Tarian klasik Yogyakarta merupakan tarian yang bersifat abstrak dan simbolis. ${ }^{2}$ Bentuk keabstrakan dan simbul-simbol dalam tari klasik tergambar dalam setiap gerak yang diatur dalam satu komposisi tertentu maupun musik yang mengiringinya. Tari klasik Yogyakarta sebagai suatu totalitas merupakan suatu perpaduan yang harmonis antara kulit luarnya yaitu gerak tubuh, kostum, ekspresi dengan substansinya yaitu jiwa dan rohnya. Oleh karena tari klasik mempunyai nilai kebatinan menggambarkan setiap gerak dan sikap akan lebih hidup, berisi dan eksprasinya lebih intens. Tari joged Mataram sebagai isi atau jiwanya dan sebagai rohnnya adalah karawitan yang mengiringinya ${ }^{3}$.

Tari klasik lahir dalam kancah pergolakan dan perjuangan mengusir penjajah, maka kelahirannya ditengah tetesan darah dan air mata. Oleh karenanya tarian ini memiliki karakteristik sebagai pejuang yang gagah, kokoh, berani dan pantang menyerah tetapi setia, sederhana dan ikhlas. Suatu sifat yang terus dikembangkan dan merupakan salah satu simbol yang digunakan manusia. Dalam hal ini manusia tidak lepas dari kodratnya sebagai “animals simbolicum”4. Sebagai mahkluk simbolik manusia dapat mengungkapkan apa yang dipahami, dirasakan dan dikehendakinya dengan simbol-simbol. Simbol sebagai salah satu aktivitas manusia yang berpola dalam mengungkapkan penuh dengan tindakan-tindakan simbolik. Hal itu disebabkan melalui seni

\footnotetext{
${ }^{2}$ Suryobrongto, GBPH, Kawruh Joged Mataram, (Yogyakarta: Yayasan
} Siswa Among Bekso, 1981), hlm. 112

${ }^{3}$ Ibid., hlm. 13-14.

${ }^{4}$ Ernst Cassirer, Manusia dan Kebudayaan: Sebuah Esei Tentang Manusia, Diterjemahkan oleh Alois A Nugroho, (Jakarta: PT Gramedia, 1987), hlm. 40. 
rasa budaya manusia yang tidak dapat diungkapkan melalui pergaulan antar manusia sehari-hari dapat dicurahkan dalam bentuk simbol seninya. ${ }^{5}$

Batik merupakan bagian dari seni budaya Indonesia terutama seni kerajinan tangan. Batik sendiri telah lama dikenal selama berabad-abad lampau, yang dapat dijumpai pada relief candi yang menggambarkan motif batik. Di Indonesia batik diapat ditemui dibeberapa daerah seperti Surakarta, Yogyakarta, Pekalongan, Cirebon, Madura, dan lain-lain. Meskipun tiap daerah mempunyai ciri motif berbeda tetapi dalam proses pembuatannya tetap sama.

Sebagai media seni rupa, batik merupakan warisan generasi lampau yang telah mengembangkan corak yang paling sederhana dan yang banyak variasinya. Timbulnya variasi dalam corak batik maka batik dapat dibedakan sebagai pakaian adat, pakaian sehari-hari dan perlengkapan hidup manusia. Untuk menahami motif suatu batik perlu pengamatan seksama karena bentukbentuknya tidak menggambarkan keadaan alam nyata seperti yang dapat ditangkap manusia. Pengungkapan gambar-gambar cenderung pada penggubahan bentuk-bentuk alam menjadi simbol-simbol yang mempunyai makna tertentu dan erat hubungannya dengan pandangan hidup. Oleh karena itu pola batik tradisional mempunyai bentuk yang telah ditetapkan oleh tradisi dan dianut oleh pendungnya sebagai kebiasan yang turun-temurun selama berabad-abad. ${ }^{6}$ Simbol-simbol apakah yang terkandung dalam seni tari dan batik adakah pesan-pesan yang ingin diungkapkan melalui media tari dan batik tradisional.

\section{B. Simbolisme Budaya}

Tari klasik Yoyakarta menggambarkan adanya penggunaan simbolsimbol yang sarat makna pesan-pesan etik dan estetik sebagai media pendidikan yang strategis untuk penanaman nilai-nilai moral dan untuk

${ }^{5}$ Budiono Herusatoto, Simbolisme Dalam Budaya Jawa, (Yogyakarta: Pt Hanindinita, 1987), hlm. 112.

${ }^{6}$ Joseph Fischer, ed.. Batik Tradition in the Life on the Javanese (Los Angeles: Lithograph Company), 1979), hlm. 921. 
membentuk kepribadian yang utuh lewat pengenalan seni budaya. Pada masa Sultan Hamangku Buwono VIII, tarian klasik juga dipergunakan sebagai strategi perjuangan moral dan usaha untuk mencari "jati diri” orang Jawa. Suatu fenomena yang nampak bahwa generasi bahwa generasi muda menganggap tari klasik Yogyakarta hanya sebagai tontonan tradisional yang tak mempunyai makna. Anggapan yang lain bahwa tari klasik gaya Yogyakarta hanya produk dan konsumsi kaum bangsawan dan wisatawan dan hanya untuk peningkatan pariwisata saja. Meski sebenarnya tarian berisi ungkapan tidak langsung akan adat, sikap jiwa, alam pikiran dan pandangan rohani yang berpangkal tolak dari budaya bangsa sendiri dan didalamnya terkandung nilai etik yang sangat dalam yang menjadi landasan bagi keutamaan watak susila.

Simbol-simbol yang terdapat dalam tari klasik gaya Yogyakarta adalah: 1) kostum; 2) gerak tari dan 3) asesoris. Tari klasik gaya Yogyakarta sangat ketat dalam disiplin, karena penarinya adalah para prajurit. Guna melatih kedisiplinan, setiap hari Sabtu diadakan perlombaan ketangkasan naik kuda dengan menggunakan senjata watang, yaitu sebuah tongkat sepanjang 3 meter yang ujungnya tumpul. Malam harinya diadakan pertunjukan wayang kulit di keraton dan diberi nama bertawang (Bubar Watangan), sebagai hiburan bagi pelomba.

Beksan Lawang adalah inspirasi dari perlombaan watangan yang oleh Sultan dijadikan beksan seremonial bahkan menjadi wakil pribadi Sultan pada resepsi pernikahan agung hari pertama di Kepatihan, dalam acara ini raja tak boleh hadir. $^{7}$ Di Keraton berlaku konsep klasik yang menganggap raja sebagai dewa atau inkarnasi dewa atau "dewa raja” dan di Jawa disebut "ratu gung binathara”, suatu ciri menonjol konsep itu adalah jarak yang sangat jauh antara raja yang sakral dan rakyat. ${ }^{8}$

7 Suryobronto, GBPH, Mengenal Tari Klasik Gaya Yogyakarta, (Yogyakarta: proyek Pengembangan Kesenian DIY, Departemen P dan K, 1981), hlm. 30.

${ }^{8}$ Soedarsono, The State Ritual Dance Drama in Court oy Yogyakarta, (Yogyakarta: Gadjah Mada University Press, 1990), hlm. 2-3. 
Tarian bedaya merupakan tarian tua yang lebih magis dari tari serimpi. Nama bedaya dikaitkan dengan akar kata "budha”, sehingga dapat dihipotesiskan sebagai bentuk tarian untuk keperluan ritus agama asli yang berasimilasi dengan agama Budha. ${ }^{9}$ Bedaya ditarikan gadis yang masih perawan dan dimaksudkan untuk memperingati pertemuan Panembahan Senopati dengan Ratu Kidul. Tarian itu hanya ditarikan dilingkungan keraton dan disebut "Bedaya Ketawang” di keraton Surakarta dan "Bedaya Semang” di keraton Yogyakarta. ${ }^{10}$ Pementasan tarian itu memakan waktu tiga jam, oleh karena itu para penarinya sebelumnya harus menjalani "laku” tertentu, seperti bersih diri dan berpuasa agar mendapat kekuatan lahir dan batin.

\section{a. Makna gerak tari}

Budaya Sanga, merupakan salah satu bentuk bedaya Yogyakarta yang ditarikan oleh sembilan orang, lima ditengah, dua di kanan dan kiri. ${ }^{11}$ Dalam diri manusia terdapat nur, rasa, roh, nafsu dan budi yang berasal dari empat daya yaitu “Tirtokamandanu” yaitu maruto, bagaskara, swasana. Semua itu menggambarkan kesempurnaan manusia yang terdiri dari jiwa raga. Karakteristik gerakan tarinya bermakna "trimurti” yaitu inti air, inti api dan inti angin yang bersatu menjadi "triloka” yang berarti lahir-hidup-mati, suatu siklus yang harus dilewati manusia.

Makna nama dalam bedaya seperti Batak, adalah ibarat kepala yang mempunyai panca indra, sehingga Jingga, Dadha dan Buntil hanya mengikuti aktivitas Batak. Jingga sebagai jalan masuk makanan, Dadha merupakan alat tubuh vital bagi kehidupan sepert jantung, paru-paru.

${ }^{9}$ Claire Holt, Art In Indonesia: Continuities and Change, (New York: Cornell University Press, 1967), hlm. 116. Untuk komposisi dalam gerakannya lihat, Nurjirwan Tirtamidjaya, “ A Bedaya Ketawang Dance Performence at the Court of Surakarta, dalam Indonesia Vol I, Arill 1967, hlm. 48-56.

${ }^{10}$ Edi Sedyawati, "Peranan Wanita Dalam Seni Pertunjukan Tradisional”, dalam Prisma No. 7, Tahun XX, Juli 1991, hlm. 25.

${ }^{11}$ Komposisi tersebut menggambarkan tubuh manusia yang terdiri dari kepala, badan (perut), tangan dan kaki. Kelima penari diengah mempunyai nama Hendel, Batak, Jangga, Dhada dan Buntil, sedang penari dikiri dan kanan disebut Hapit "Ngajeng” dan "Wingking”. Bagaimana memulai dan mengakhiri tarian, lihat Claire Hold, loc. cit . 
Buntil melambangkan alat kelamin untuk berkembang biak. Hapit menggambarkan dimensi rohaniyah (dalam Islam disebut Syariat) meliputi: Tarekat ( tindakan), Hakikat (kesempurnaan), Ma/rifat menjadi tujuan untuk mengerti sifat-sifat Tuhan dan manusia harus menyerahkan jiwa raganya pada Tuhan.

Gerak Hendel melawan Batak menggambarkan pertentangan antara kebaikan dan kejahatan. Jika kejahatan mengasai manusia maka ia akan jauh dari keutamaan tetapi sebaliknya jika manusia mampu mengalahkan kejahatan maka akan mencapai keutamaan. Perlawanan Hendel dan Batak juga menggambarkan pertemuan antara pria dan wanita yang dalam relief candi digambarkan sebagai 'lingga - yoni”. Oleh karena tarian bedaya merupakan tarian ritual untuk meminta kemakmuran dan kesuburan.

Gerak-gerak dalam tari bedaya baik gerak tangan, kepala maupun badan merupakan gerak-gerak yang tidak putus-putus. Hal ini menggambarkan kesinambungan yang tanpa henti, sutu gambaran siklus hidup manusia , lahir, hidup, dan berkembang lalu mati. Semua penari bedaya umumnya wanita karena hanya wanita yang dianggap dapat menghasilkan gerak-gerak indah sehingga bisa dinikmati penontonya.

\section{b. Makna pakaian dalam tari}

Kain yang digunakan dalam tari bedaya adalah cinde yang bermotif jlamprang. Motif itu berbentuk bulat dan dipusatnya terdapat bulatan kecil yang berbentuk seperti subang dan bermakna delapan kiblat dan penjuru, juga bermakna menggambarkan senjata cakra yang berujung delapan. Dalam pengetahuan candra sengkala kata badan memiliki watak delapan sebab badan dari Siwa dalam pengejawantahannya dapat terurai menjadi delapan yang meliputi: 1) Rawi = matahari, 2) Sasa = bulan, 3) Ksiti = tanah, 4) Jala = air, 5) Panama $=$ angin, 6) Hutasana $=$ api, 7) Yajamana = pendeta pemuka keselamatan, 8)Akasa = udara. Kesemuanya itu menggambarkan arah mata angin, yang menurut kepercayaan Jawa-HinduIslam merupakan bentuk cakra atau jantra sebagai lambang hidup kekal. 
Masa Islam di Jawa diibaratkan Wali Sanga, satu menjadi pusat dan yang delapan sebagai sinar.

Kain lain adalah yang bermotif semen atau semi yang berarti ada seminya. Motif kain yang berbentuk tumbuh-tumbuhan umumnya mengandung pengertian suci dalam hubungannya dengan kepercayaan. Motif tumbuhan terdiri dari tumbuhan dari sorga dan arcapada yang jadi milik Sang Hyang Wisnu. ${ }^{12}$

\section{c. Makna assesoria dalam tari}

Asesoris disini secara simbolis mempunyai makna, seperti cunduk mentul, kelat bahu, kalung, gelang dan buntal. Cunduk menggambarkan matahari yng selalu bersinar, sehingga merupakan lambang hidup manusia. Kelat bahu dengan bentuk seekor ular naga melambangkan kemakmuran. Kalung yang digunakan adalah kalung sungsum yang berbentuk tanggalan atau bulan muda. Bulan melambangkan kewanitaan, jumlahnya gasal dan bersifat positif. Secara keseluruhan kalung menggambarkan arti hidup seorang wanita. Gelangnya adalah "kana” artinya adalah "simpai atau "suh”. Buntal menggambarkan matahari dengan berbagai warna, sehingga menghasilkan perpaduan warna yang indah dan harmonis. ${ }^{13}$

\section{Simbolisme Batik}

Motif batik adalah kerangka yang mewujudkan batik secara keseluruhan dan disebut sebagai pola batik atau corak batik. Menurut unsurnya motif batik dapat dibagi menjadi dua bagian utama yaitu ornamen dan isen. Ornamen terdiri dari ornamen utama dan ornamen tambahan atau pengisi bidang. Pengaruh alam sangat menonjol dalam pola batik yang berujud bunga, ikan, burung dan pohon anggur. Motif batik diciptakan dengan tujuan tertentu yang dapat dilihat dari kegunaannya dan lambangnya.

\footnotetext{
${ }^{12}$ Kuswadji Kawendrasusanto, 'Mengenal Tari Klasik Gaya Yogyakarta”, hlm. 164-170.

${ }^{13}$ Ibid, hlm. 171.
} 
Kegunaan, yang berlatar ireng biasa digunakan oarng tua dan orang muda lebih sering menggunakan yang latar putih. Batik juga dilihat dari ukuran gambarnya yang lebih kecil biasa digunakan untuk perempuan, sedangkan pria menggunakan ukuran gambar yang lebih besar. Joka dilihat dari penggunanya juga berbeda untuk motif sawat (huk, mlinjon) hanya untuk Sultan sampai turunan kelimanya saja dan rakyat menggunakan yang lain.

Lambang, motif batik dapat menggambarkan amkna tertentu, seperti: 1). Keagungan/kejayaan, kebanyakan terdapat dalam ornamen garuda atau gambar lain yang besar seperi parang, kawung,ceplo; 2) kemakmuran; terdapat dalam ornamen folra; 3) kedamaian, menggambarkan kesatuan hubungan manusia dan alam yang digambarkan dengan flora dan fauna; 4) ketenteraman, dalam motif flora dan fauna yang menggambarkan kebahagian lahir dan batin; 5) kesejahteraan, terdapat pada motif sepasang burung; 6) kesucian, dalam motif bunga teratai; 7) keindahan, tidak menunjukkan makna tertentu kecuali keindahan.

Motif batik jika ditinjau dari ornamen utamanya terdiri dari:

1. Meru, menggambarkan unsur tanah atau bumi tempat tumbuh dan berkembang atau disebut "semi” (bahasa Jawa atau semen

2. Api/lidah api, digambarkan sebagai deretan nyala api.motif ini sebagai hiasan pinggir atau batas antara bidang motif dan tidak bermotif yang biasa disebut cemukiran atau modang.

3. Ular/naga) tan nyala api, adalah bentuk khayalan yang digambarkan seperti kepala raksasa bermahkota, kadang berkaki, kadang bersayap. Jika dua naga digambarkan simetris menjadi mirip garuda. Naga menyimbulkan dunia bawah, air, perempuan, yoni, pintu dan musik.

4. Burung, terdiri dari tiga macam yaitu merak, phonix dan burung khayalan.

5. Garuda/lar garuda menjadi motif ciri batik Indonesia yang digambarkan sebagai burung yang kuat. Sebagai motif khayalan yang kadang digambarkan kepalanya atau ssyapnya saja.

6. Pohon hayat, sebagai bentuk pohon khayalan yang bersifat perkasa dan sakti sebagai lambang kehidupan dan juga disebut sebagai pohon surga. 
Bentuknya gambaran lengkap dari batang, dahan, akar, putik maupun bunga.

7. Tumbuhan, digambarkan secara stilir dari salah satu bagian pohon

8. Candi atau perahu (bangunan), menggambarkan semacam rumah baik lantai atau atap. Ornamen tersebut bersifat keramat yang tidak diketahui apakah fungsi bangunan tersebut, apakah sebagai candi, istana, balai kambang, atau gambaran tandu atau perahu.

9. Binatang dan kupu-kupu, digambarkan dalam ornamen lembu, kijang, gajah, singa atau harimau dengan gambar keperkasaan dan kesaktiannya.

Motif batik yang susunan ornamennya merupakan geometris dengan motif lingkara, segi empat atau segi tiga terdiri dari: 1) motif banji, 2) motif ganggong, 3) motif ceplokan, 4) motif seperti anyaman, 5) motif parang atau lereng dan 6) motif kawung. Motif yang non geometris dengan susunan tidak teratur dan merupakan pengulangan kembali susunan motif, antara lian motif semen, motif buketan atau terang bulan dan motif-motif dinamis.

\section{a. Makna motif batik geometris}

Motif banji disebut juga batik "kerton” menggambarkan swastika yang bermakna perputaran roda kehidupan serta melambangkan kedamaian antara manusia dan alam. Banji melambangkan keagungan, kedamaian, ketenteraman dan keindahan. Motif ganggong seperti motif ceplok tapi bedanya ada isian garis-garis yang panjangnya tidak sama dan yang pailing panjang berbentuk sabit. Motif ini menggambarkan kemakmuran, kedamaian, kesejahteraan, dan keindahan. Motif ceplokan merupakan motif yang di didalamnya terdapat lingkaran, binatang dan variasinya. Motif batik ceplok menggambarkan kemakmuran, kedamaian, kesejahteraan, dan keindahan. Motif nitik atau anyaman merupakan motif semacam ceplok yang tersusun dari garis-garis putus, titik-titik yang sepintas seperti anyaman. Motif ini melambangkan keindahan. Motif kawung tersusun dalam bentuk elip menurut diagonal miring kiri atau kanan berselang seling. Gambar yang kecil lebih feminim dan diperuntukkan bagi perempuan dan sebaliknya disenangi lelaki adalah gambar yang besar. Motif kawung 
menenggambarkan keagungan, ketenteraman, kesucian dan keindahan. Motif parang atau lereng adalah motif yang tersusun menurut garis miring yang menggambarkan kemakmuran, ketenteraman dan keindahan.

\section{b. Motif non geometris}

Motif yang termasuk non geometris adalah semen yang berasal dari kata semi atau pertumbuhan. Motifnya terdiri dari flora yang kadang diseling fauna dan menggambarkan semua unsur kehidupan yaitu dari keagungan sampai keindahan. Batik tradisional kadang memadukan beberapa motif sehingga menjadikan keragaman makna batik itu sendiri.

\section{Globalisasi Kebudayaan}

Perkembangan transportasi dan komunikasi ikut mempengaruhi batik terutama adanya akulturasi baik motif maupun warna. Batik tradisional menunjukkan adanya akulturasi dengan budaya-budaya Hindu, Budha, Islam maupun Barat atau Eropa. Unsur Hindu dan Budha terdapat pada motif candi maupun bangunan, unsur Islam terlihat pada penggambaran makhluk hidup yang tidak utuh yaitu dengan menstilir sebagian saja dari organ hidup, pengaruh Eropa terlihat pada penggambaran yang sebaliknya dari pengaruh Islam. Motif-motif digambarkan dengan lengkap dan utuh dan terdapat juga pengauh Cina pada motif banji dan mega mendung.

Pengaruh teknologi membawa batik dalam, produksi massal yaitu penggunaan mesin cetak. Proses karya batik tradisional yang mengutamakan keindahan alami dengan sederhana dirubah dengan kecanggihan teknologi. Pembuatan batik trasional yang memakan waktu lama dengan harga tinggi diganti dengan mesin yang menghasilkan batik lebih murah. Dari segi ekonomi memang menunjukkan keuntungan dan semakin banyak orang yang dapat membelinya.

Globalisasi sebagai kondisi yang tak terhindarkan membawa dampak juga pada perkembangan batik tradisional. Jawa dikenal semakain luas. Perkembangan mode dunia juga menjadikan batik sebagai salah satu bahan peragaannya. Beberapa waktu lalu Amerika melangsungkan lomba membatik 
dalam lukisan dan batik yang dihasilkannya menunjukkan corak flora dan fauna Amerika. Dengan demikian batik semakin bervariasi tergantung mana yang mengembangkannya, tetapi tentu saja tidak mengurangi kekhasan batik Jawa. lebih bercorak.

Munculnya hukum Hak atas Kekayaan Intelektual atau HAKI meliputi bidang hak cipta, paten dan merek, di Indonesia merupakan fenomena baru dalam industri dan perdagangan. Implikasinya di Indonesia menimbulkan permasalahan antara aturan baru dalam ekonomi dan industri sedang masyarakat dengan sosial budaya yang masih dalam transisi industrial. HAKI yang muncul didunia Barat sangat bertentangan dengan corak masyarakat ketimuran yang mengedepankan nilai-nilai kebersamaan. Apabila mereka mempunyai karya dan bermanfaat bagi banyak orang, maka mereka akan bangga dan tidak memasalahkan jika karyanya ditiru orang lain karena merasa senang karyanya disebarluaskan dan dikenal banyak orang ${ }^{14}$. Adanya keharusan mendaftar ke HAKI untuk mendapat perlindungan hukum di negaranegara Asia dipandang menjadi kendala karena corak seperti itu terasa asing dan hanya ada sebagai peninggalan kolonial yang keberadaannya bertentangan dengan tradisi hukum Asia yang bercorak komunal. ${ }^{15}$

Perilaku meniru di kalangan pengusaha batik dianggap sebagai kelaziman, disebabkan masih kuatnya bahwa batik sebagai produk budaya yang sudah lama dikenal dan dianggap milik masyarakat komunal. Beberapa pengusaha batik merasa tidak setuju terhadap pendaftaran motif batik kontemporer, karena pada hakikatnya merupakan hasil mengembangan motif batik tradisional ${ }^{16}$. Oleh karenanya yang harus dilindungi justru motif tradisional dari peniruan asing dan ekspoloitasi pengusaha dengan printing karena akan merendahkan nilai kesakralan batik tradisional.

Dalam seni tari juga demikian tidak melalui pendaftaran HAKI tetapi seni tari tradisional adalah ciri khas budaya Jawa sudah lama dikenal. Guna

\footnotetext{
${ }^{14}$ Maryadi, ed., Transformasi Budaya, (Surakarta: Muhammadyah
} University Press, 2000), hlm. 53-54.

${ }^{15}$ Ibid. 
mempertahankan ketradisionalannya maka seni tradisi memang seharusnya dijaga supaya tidak terpengaruh barat atau asing dalam segalanya baik musiknya dan pakaiannya, misalnya menggunakan rekaman dari kaset atau vidio. Yang tetap dapat menjadi ciri ketradisionalan tari adalah geraknya yang khas dan penuh makna filosofis.

\section{E. Kesimpulan}

Globalisasi merupakan kondisi yang tidak dapat dielakkan, tetapi dapat disikapi dengan bijak agar tidak terlalu memaksakan suatu perubahan. Apabila harus menyesuaikan dengan pangsa industri, maka harus sesuai dengan corak Indonesia sebagai masyarakat komunal yang harus disertai strategi hukum yang tepat untuk melindungi seni tradisi. Jika negara-negara industri ingin memanfaatkan keadaan di Indonesia, maka upaya yang dapat dilakukan adalah bagaimana kita mengantisipasi untuk memanfaatkannya.

Untuk mengantisipasi globalisasi kita perlu sosialisasi secara intensif melalui berbagai media penyuluhan dan pelatihan terutama untuk industri tradisional. Disamping itu juga perlu jaminan perlindungan yang didasarkan pertimbangan budaya dan kepentingan ekonomi dengan tidak menghilangkan ketradisionalannya.

\section{Daftar Pustaka}

Budiono Herusatoto, Simbolisme Dalam Budaya Jawa, Yogyakarta: PT Hanindinita, 1987.

Cassirer, Ernst, Manusia dan Kebudayaan: Sebuah Esei Tentang Manusia, Diterjemahkan oleh Alois A Nugroho, Jakarta: PT Gramedia, 1987.

Djoko Soekiman, Kebudayaan Indis dan Gaya Hidup Masyarakat Pendukungnya di Jawa (Abad XVIII Sampai Medio Abad XX), 1997.

Hari Poerwant0, Kebudayaan dan Lingkungan dalam Perspektif Antropologi, Yogyakarta: Pustaka Pelajar, 2000. 
Holt, Claire, Art In Indonesia: Continuities and Change, New York: Cornell University Press, 1967.

Koentjaraningrat, Manusia dan Kebudayaan di Indonesia, Jakarta: Djambatan, 1997.

---------, Pengantar Ilmu Antropologi, Jakarta: Aksara Baru, 1986.

Kuswadji Kawendrasusanto, 'Mengenal Tari Klasik Gaya Yogyakarta”

Maryadi, ed., Transformasi Budaya, Surakarta: Muhammadyah University Press, 2000.

Nurjirwan Tirtamidjaya, “ A Bedaya Ketawang Dance Performence at the Court of Surakarta, dalam Indonesia Vol I, Arill 1967.

Soedarsono, The State Ritual Dance Drama in Court oy Yogyakarta, Yogyakarta: Gadjah Mada University Press, 1990.

Suryobrongto, GBPH, Kawruh Joged Mataram, Yogyakarta: Yayasan Siswa Among Bekso, 1981.

----------, Mengenal Tari Klasik Gaya Yogyakarta, Yogyakarta: Proyek Pengembangan Kesenian DIY, Departemen P dan K, 1981.

Tim Lembaga Research Kebudayaan Nasional LRKN-LIPI, Kapita Selekta Manifestasi Budaya Indonesia, Bandung: Badan Penelitian dan Pengembangan Departemen Luar Negeri dan Alumni, 1984.

Van Peursen: Strategi Kebudayaan, Yogyakarta: Kanisius, 1985. 